\title{
Physicochemical Status of Sitalakkhya River, an Ecologically Critical Area (ECA) of Bangladesh
}

\section{Bidhan Bhuson Roy, Rezuana Afrin*, Subodhe Chandra Barman, Md. Younus Mia}

Department of Environmental Science and Resource Management, MawlanaBhashani Science and Technology University, Tangail-1902, Bangladesh.

*Corresponding authors e-mail: afrin.mbstu038@gmail.com

\begin{abstract}
The study was conducted to assess the water quality of the Sitalakk hya River, Narayangonj, Bangladesh and observe its temporal changes forthe physicochemical parameters of water from March to May, 2015. The present study showed that the color of water was deep black or black and emittedobnoxious smell. It was found in the study that the temperature, transparency, TDS, EC, $p H, D O$, alkalinity, hardness, $\mathrm{NO}_{3}{ }^{-}, \mathrm{Cl}^{-}$and $\mathrm{BOD}$ were ranged from 31.5-34.6 ${ }^{\circ} \mathrm{C}, 15.25-27.30 \mathrm{~cm}, 291-781 \mathrm{ppm}, 558-2664 \mathrm{ppm}$, 7.57-8.60, 1.4-3.6 ppm, 123-435 ppm, 203-332 ppm, 0$89.13 \mathrm{ppm}, 51.68-237.36 \mathrm{ppm}$ and 3.21-17.3 ppm, respectively. Most of the observed parameters have exceeded permissible limits except $\mathrm{pH}$ and $\mathrm{Cl}^{-}$indicating higher concentrations of organic and inorganic pollutants present in the river.According to the study, significant strong positive correlations were found in temp. vs $\mathrm{pH}(\mathrm{r}=$ 0.774, $p<0.05)$, temp. vsCl- $(r=0.954, p<0.05)$, temp. vs BOD ( $r=0.747, p<0.05), T D S$ vs EC $(r=0.955, p<0.05)$, $p H v_{s C l}^{-}(r=0.808, p<0.05), p H$ vs BOD $(r=0.864, p<$ $0.05)$ and $\mathrm{DO} \mathrm{vsNO}_{3}^{-}(r=0.758, p<0.05)$ in March; temp. vsNO $3^{-}(r=0.915, p<0.05), T D S$ vs EC $(r=0.949, p<0.05)$, TDS vs DO ( $r=0.765, p<0.05)$ and DO vshardness $(r=$ 0.745, $p<0.05)$ in April andtransparency vsNO${ }^{-}(r=0.906$, $p<0.05), T D S$ vs EC ( $r=0.922, p<0.05), T D S$ vs $p H(r=$ 0.836, $p<0.05), E C v s p H(r=0.982, p<0.05)$ and $p H v s$ hardness ( $r=0.764, p<0.05)$ in May. Significant strong negative correlations were found in EC vs alkalinity ( $r=$ 0.745, $p<0.05), \mathrm{DO} v \mathrm{BOOD}(r=-0.876, p<0.05)$ and $\mathrm{NO}_{3}$ vs BOD ( $r=-0.765, p<0.05)$ in March and TDS vsCl- $(r=-$ 0.774, $p<0.05), \mathrm{EC} \mathrm{vsCl}^{-}(r=-0.758, p<0.05)$, hardness vs BOD $(r=-0.775, p<0.05)$ and $\mathrm{NO}_{3}{ }^{-} v s C l^{-}(r=-0.763, p<$ 0.05) in April.The hydrochemistry of the water body has revealed that the water is unsafe for human health, aquatic organisms and also for household, irrigational and industrial uses without proper treatment.
\end{abstract}

Keywords- Sitalakkhya River, water quality, physicochemical parameter.

\section{INTRODUCTION}

Bangladesh is one of those polluted countries, which currently holds 1176 industries that discharge about 0.4 million $\mathrm{m}^{3}$ of untreated waste to the rivers in a day [17]. In terms of quality, the surface water of the country is vulnerable to pollution from untreated industrial effluents and municipal wastewater, runoff from chemical fertilizers and pesticides, and oil and lube spillage in the coastal area from the operation of sea and river ports. Water quality also depends on effluent types and discharge quantity from different types of industries, types of agrochemicals used in agriculture, and seasonal water flow and dilution capability by the river system [7].

Dhaka city is surrounded by a number of rivers and canals of which Turag, Sitalakkhya, Buriganga, Dhaleshwari and Balu are the important ones. The surface water along these peripheral rivers of Dhaka city is known to be highly polluted due to municipal and industrial untreated waste waters that are discharged into these rivers [15]. Pollution is so severe in the Buriganga, Sitalakkhya and Balu rivers that it is almost impossible to treat the water for making it suitable for human use. For this critical situation, on September 2009, Department of Environment (DoE) declared Buriganga,Sitalakhya and Balu rivers as Ecologically Critical Area (ECA) [8].

The river Sitalakkhya is one of the most prominent rivers in the flood plain region of Bangladesh. It is located in Narayangonj City, the second most vital industrial zone of the country. In spite of being an Ecologically Critical Area huge quantities of untreated domestic and industrial wastes are being released every day in the Sitalakkhya River. The water quality of this river is deteriorating rapidly, especially during dry season at certain reaches of the river [1]. 
The wastes, effluents and agrochemicals contain heavy metals, toxic substances, germs and nitrogen containing toxic substances which pollute the natural system of Sitalakkhya River and it actually acts as a sink. Thus a serious environmental hazards is created which endangers human health and cause problems to aquatic lives. So, the Sitalakkhyariver needs attention to save it from destruction. The objective of the present study is to assess the water quality of Sitalakkhyariver by analyzing physicochemical parameters and make a temporal correlational analysis .

\section{MATERIALS AND METHODS}

\subsection{Study area}

The study was conducted from March to May, 2015 at the Sitalakkhya River in Narayangonj (Fig. 1). Sitalakshya River is a distributary of the Brahmaputra. In its initial stages it flows in a southwest direction and then east of the city of Narayangonj in central Bangladesh until it merges with the Dhaleshwari near Kalagachhiya. The river is about 110 kilometers (68 miles) long and at its widest, near Narayangonj, it is 300 meters (980 ft) across.

\subsection{Sample collection}

Water samples were collected from 6 sites of the river namely S-1 (Taraboghat), S-2 (Taitkkakhal), S-3 (Shenpara), S-4 (Kachpur Bazar) and S-5 (Monjilkhola) and S-6 (Shiddhirgonj) from March to May, 2015. Samples were collected in $250 \mathrm{ml}$ black coated plastic bottles with three replications from each point. Prior to sample collection, all bottles were cleaned with distilled water.

\subsection{Sample analysis}

The water quality parameters such as temperature and $\mathrm{pH}$ were determined by the thermometer and digital $\mathrm{pH}$ meter (model-pH Scan WP 1, 2, Malaysia), respectively. Transparency was measued by secchi disc by following proper method [21]. Electrical Conductivity (EC) and Total Dissolved Solids (TDS) were determined by digital EC meter and digital TDS meter (model-HM digital, Germany), respectively. Dissolved oxygen (DO) was determined by digital DO meter (model-D. 46974, Taiwan). Alkalinity was measured by titration method and the EDTA method was used to determine the hardness of water. The biological oxygen demand (BOD) was measured by two steps incubation method [21 and 12].

\subsection{Statistical analysis}

The physicochemical parameters for all the study sites were analyzed by calculating Pearson's correlation coefficient (r) value.

\section{RESULTS AND DISCUSSIONS} 3.1 Physicochemical Properties of the Study Area

The observed water color was black in all sampling stations. But phytoplankton enriched dark greenish blue, red or brown color is good for fishes [6] and the standard is colorless [23].

During the study period (at all sampling stations) the maximum water temperature $34.6^{\circ} \mathrm{C}$ was recorded in May (S6) and minimum $31.5^{\circ} \mathrm{C}$ was recorded in March (S1) (Table 1). In case of river water temperature, the DoE standard for sustaining aquatic life is within 20 to $30^{\circ} \mathrm{C}$ both in dry and wet season [4] and all the observed values exceeded the standard limit indicating higher level of pollutants in water. In the study, temperature showed significant strong positive correlation with $\mathrm{pH}(\mathrm{r}=0.774, \mathrm{p}<$ $0.05), \mathrm{Cl}^{-}(\mathrm{r}=0.954, \mathrm{p}<0.05)$ and BOD $(\mathrm{r}=0.747, \mathrm{p}<0.05)$ in March and $\mathrm{NO}_{3}^{-}(\mathrm{r}=0.915, \mathrm{p}<0.05)$ in April. A study found the temperature of the Sitalakkhya river varied from 20.5 to $31.3^{0} \mathrm{C}$ [13]. Many mills and factories are constructed on the bank of this river who use the river's water for cooling purpose and also dispose the wastes into the river thus increase the temperature.

The maximum water transparency value $27.30 \mathrm{~cm}$ was recorded in May (S5) and minimum 15.25 cmwas recorded in March (S1) (Table 1). According to WHO, the standard value of transparency is $40 \mathrm{~cm}$ and transparency levels are low at all sampling points. In the study, transparency showed significant strong positive correlation with $\mathrm{NO}_{3}{ }^{-}(\mathrm{r}=$ 0.906, $\mathrm{p}<0.05$ ) in May.

The observed maximum TDS value $781 \mathrm{ppm}$ was recorded in April (S1) and minimum 291 ppmwasrecorded in May (S1) (Table 1).High TDS value indicatesthe presence of an appreciable quantities of bicarbonates, sulfates and chlorides of $\mathrm{Ca}, \mathrm{Mg}$ and $\mathrm{Na}[14]$.In the study, TDS showed significant strong positive correlation with ECin March $(r=$ $0.955, \mathrm{p}<0.05)$, April $(\mathrm{r}=0.949, \mathrm{p}<0.05)$ and May $(\mathrm{r}=$ $0.922, \mathrm{p}<0.05)$; DO $(\mathrm{r}=0.765, \mathrm{p}<0.05)$ in April and $\mathrm{pH}(\mathrm{r}=$ $0.836)$ in May and significant strong negative correlation with $\mathrm{Cl}^{-}(\mathrm{r}=-0.774, \mathrm{p}<0.05)$ in April.A study found the TDS of the Sitalakkhyariver varied from 80 to $754 \mathrm{ppm}$ [13]. Dumping of industrial wastes is mainly responsible for increasing TDS level in this river.

The observed maximum EC value $2664 \mu \mathrm{S} / \mathrm{cm}$ was recorded in March (S2) and minimum $558 \mu \mathrm{S} / \mathrm{cm}$ was recorded in May (S1) (Table 1).The standard value of EC is $250 \mu \mathrm{S} / \mathrm{cm}$ [23] and all the values were greater than the permissible limit indicating presence of ionic compounds as well as higher concentration of inorganic pollutants in 

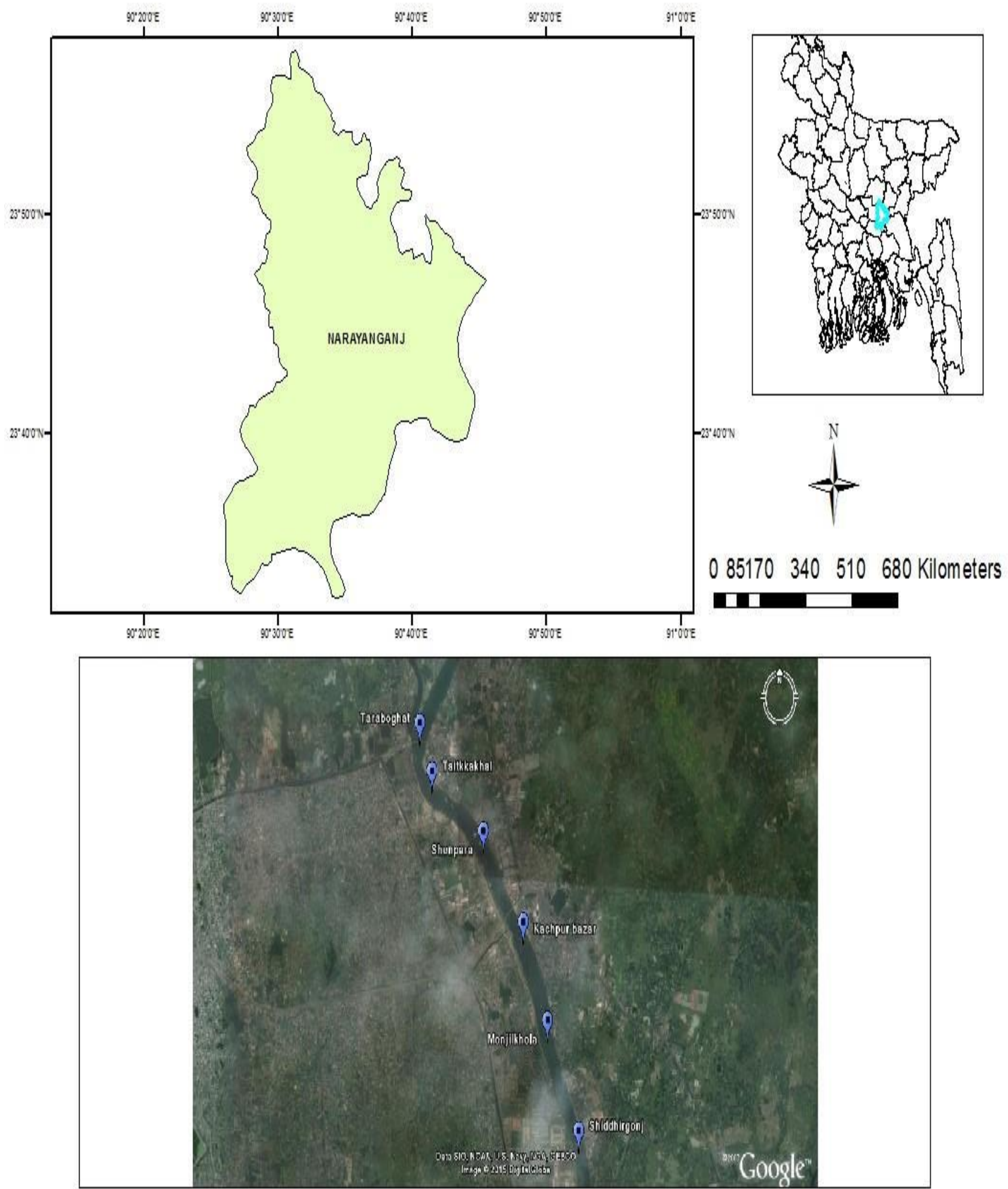

Fig. 1: Map showing the study area with sample collection points. 
water.In the study, EC showed significant strong positive correlation with $\mathrm{pH}(\mathrm{r}=0.982, \mathrm{p}<0.05)$ in May; significant strong negative correlation with alkalinity $(\mathrm{r}=-0.745, \mathrm{p}<$ $0.05)$ in $\mathrm{March}$ and $\mathrm{Cl}^{-}(\mathrm{r}=-0.758, \mathrm{p}<0.05)$ in April.A study found the EC of the Sitalakkhyariver varied from 121 to $1167 \mu \mathrm{S} / \mathrm{cm}$ [13]. Releasing chemical wastes containing ionic compounds causes increase in $\mathrm{EC}$ level in this river. In this study, the maximum $\mathrm{pH}$ value 8.60 was recorded in April at Station- 2 (S2) and minimum 7.57was recorded in May at Station-1 (S1) (Table 1) and all the observed values were within the standard range (6.5-9.0). In the study, $\mathrm{pH}$ showed significant strong positive correlation with $\mathrm{Cl}^{-}(\mathrm{r}=$ $0.808, \mathrm{p}<0.05)$ and BOD $(\mathrm{r}=0.864, \mathrm{p}<0.05)$ in March and hardness $(r=0.764, p<0.05)$ in May. A study found the $\mathrm{pH}$ of the Sitalakkhya river varied from 6.9 to 8.0 [13]. Most of the industries use lime to neutralize the acidic condition of the effluents before releasing into the atmosphere thus the $\mathrm{pH}$ level of this river water is almost neutral.

The maximum DO value $3.6 \mathrm{ppm}$ was recorded in May (S6) and minimum 1.4was recorded in March (S3) (Table 1). The standard range of DO for fish culture is from $5 \mathrm{ppm}$ to saturation [16] and all the observed values were below the standard level. DO levels of $3 \mathrm{ppm}$ or lower should be regarded as hazardous to lethal under stream and lake conditions [9]. Such low value of DO indicates presence of high organic compounds in water and doesn't support the survival of aquatic life. In the study, DO showed significant strong positive correlation with $\mathrm{NO}_{3}{ }^{-}(\mathrm{r}=0.758, \mathrm{p}<0.05)$ in March and hardness $(r=0.745, p<0.05)$ in April and significant strong negative correlation with BOD $(r=-0.876$, $\mathrm{p}<$ 0.05) in March. A study found the DO of the Sitalakkhyariver varied from 0.5 to $3.5 \mathrm{ppm}$ [13]. Huge industrial and household loads are responsible for decreasing DO level in this river and also indicates huge microbial growth in water.

The maximum alkalinity 435 ppm was recorded in March (S4) and minimum 123 ppmwas recorded in May (S3) (Table 1). The standard level of alkalinity is $<100$ ppm [18] and all the observed values were higher than this standard value indicating high alkaline condition of water.

The maximum hardness $332 \mathrm{ppm}$ was recorded in April (S2) and minimum 203 ppmwas recorded in March (S4) (Table 1). The counter-ions associated with the bicarbonate and carbonate fraction of alkalinity are the principal ions responsible for hardness [3]. The standard level of hardness is $123 \mathrm{ppm}$ [12] and all the observed values were higher than this standard value. In the study, hardness showed significant strong negative correlation with BOD $(r=-0.775$, $\mathrm{p}<0.05)$ in April. Increasing level of chemical wastes disposal causes high hardness level of water.

In the present study, the maximum Nitrate $\left(\mathrm{NO}_{3}{ }^{-}\right)$value $89.13 \mathrm{ppm}$ was recorded in April (S3) and minimum 0 ppmwas recorded in March (S3 and S4) (Table 1). Nitrate reactions $\left(\mathrm{NO}_{3}{ }^{-}\right)$in fresh water can cause oxygen depletion. Thus aquatic organisms depending on the supply of oxygen in the stream can perish. Non-point pollution sources such as agriculture and livestock may have contributed to the increased $\mathrm{NO}_{2}^{-}$and $\mathrm{NO}_{3}^{-}$in the rivers of developing countries especially in Bangladesh and Indonesia [20]. Here, most of the observed values were higher than the standard $\mathrm{NO}_{3}^{-}$value which is $10 \mathrm{ppm}$ [22]. In the study, $\mathrm{NO}_{3}$-showed significant strong negative correlation with BOD $(r=-0.765, p<0.05)$ in March and $\mathrm{Cl}^{-}(\mathrm{r}=-0.763, \mathrm{p}<$ $0.05)$ in April. Disposal of wastes containing high ionic compounds causes high $\mathrm{NO}_{3}{ }^{-}$level.

The maximum Chloride $\left(\mathrm{Cl}^{-}\right)$value $237.36 \mathrm{ppm}$ was recorded in April (S2) and minimum 51.68 ppmwas recorded in March (S1) (Table 1). Here, all the observed values were within the standard level of $\mathrm{Cl}^{-}$which is 600 ppm [23].

The maximum BOD value $17.3 \mathrm{ppm}$ was recorded in April (S3) and minimum 3.21 ppmwas recorded in May (S2) (Table 1).The BOD values showed high fluctuations primarily due to the addition of effluent from industries and also because of dilution by river water [2].Unpolluted waters typically have BOD values of $2 \mathrm{ppm}$ or less [5]. Here, most of the observed valueswere higher than the standard BODvalue which is 5-7 ppm [10] because of the discharge of huge untreated sewage in the study area.It also indicated the presence of comparatively more organic waste in the river water [19].High BOD level indicates high amount of biodegradable wastes in the river water.

\subsection{Pearson Correlation}

Pearson correlations were done among the analyzed physicochemical parameters of Sitalakkhyariver (Table 2, 3 and 4). 
Table 1. Variations in physicochemical properties of Sitalakkhya River (March-May, 2015).

\begin{tabular}{|c|c|c|c|c|c|}
\hline Parameters & $\begin{array}{l}\text { Sampling } \\
\text { Stations }\end{array}$ & March & April & May & Standards \\
\hline \multirow{7}{*}{ Temperature $\left({ }^{0} \mathrm{C}\right)$} & S1 & 31.5 & 32.3 & 33.5 & \multirow[t]{7}{*}{$20-30^{\circ} \mathrm{C}[11]$} \\
\hline & S2 & 32.6 & 31.8 & 34.3 & \\
\hline & S3 & 33.7 & 32.2 & 33.8 & \\
\hline & $\mathrm{S} 4$ & 33.4 & 32.2 & 34.3 & \\
\hline & S5 & 33.1 & 32.2 & 34.4 & \\
\hline & S6 & 33.4 & 32.4 & 34.6 & \\
\hline & Mean \pm SD & $32.95 \pm 0.80187$ & $32.18 \pm 0.20$ & $34.15 \pm 0.41352$ & \\
\hline \multirow{7}{*}{ Transparency $(\mathrm{cm})$} & S1 & 15.25 & 19.57 & 21.50 & \multirow[t]{7}{*}{$40 \mathrm{~cm} \mathrm{[23]}$} \\
\hline & $\mathrm{S} 2$ & 16.25 & 22.15 & 25.25 & \\
\hline & S3 & 16.8 & 16.6 & 23.70 & \\
\hline & S4 & 18.35 & 19.1 & 19.50 & \\
\hline & S5 & 17.07 & 26.57 & 27.30 & \\
\hline & S6 & 15.75 & 19.50 & 22.75 & \\
\hline & Mean \pm SD & $16.58 \pm 1.09$ & $20.58 \pm 3.42$ & $23.33 \pm 2.75$ & \\
\hline \multirow{7}{*}{ TDS (ppm) } & S1 & 663 & 781 & 291 & \multirow[t]{7}{*}{ 500pp [22] } \\
\hline & S2 & 729 & 394 & 300 & \\
\hline & S3 & 670 & 412 & 316 & \\
\hline & S4 & 675 & 618 & 319 & \\
\hline & S5 & 674 & 424 & 309 & \\
\hline & S6 & 656 & 420 & 326 & \\
\hline & Mean \pm SD & $677.83 \pm 26.07$ & $508.16 \pm 157.25$ & $310.16 \pm 12.92$ & \\
\hline \multirow{7}{*}{$\mathrm{EC}(\mu \mathrm{S} / \mathrm{cm})$} & S1 & 1288 & 1184 & 558 & \multirow{7}{*}{$\begin{array}{l}250 \mu \mathrm{S} / \mathrm{cm} \\
{[23]}\end{array}$} \\
\hline & S2 & 2664 & 738 & 581 & \\
\hline & S3 & 1267 & 772 & 615 & \\
\hline & S4 & 1298 & 1175 & 623 & \\
\hline & S5 & 1398 & 792 & 608 & \\
\hline & S6 & 1364 & 778 & 613 & \\
\hline & Mean \pm SD & $1546.5 \pm 549.70$ & $906.5 \pm 212.23$ & $599.66 \pm 24.95$ & \\
\hline \multirow{7}{*}{$\mathrm{pH}$} & S1 & 7.88 & 8.59 & 7.57 & \multirow[t]{7}{*}{$6.5-8.5[22]$} \\
\hline & S2 & 7.98 & 8.60 & 7.77 & \\
\hline & S3 & 8.30 & 8.58 & 8.00 & \\
\hline & S4 & 7.99 & 8.26 & 8.09 & \\
\hline & S5 & 8.04 & 8.58 & 7.97 & \\
\hline & S6 & 8.07 & 8.07 & 7.92 & \\
\hline & Mean \pm SD & $8.04 \pm 0.14$ & $8.45 \pm 0.23$ & $7.88 \pm 0.18$ & \\
\hline \multirow{7}{*}{ DO (ppm) } & S1 & 2.2 & 3.4 & 3.55 & \multirow[t]{7}{*}{ 4-6 ppm [22] } \\
\hline & S2 & 2.1 & 3 & 2.55 & \\
\hline & S3 & 1.4 & 2.8 & 2.4 & \\
\hline & S4 & 2.0 & 2.9 & 2.9 & \\
\hline & S5 & 2.6 & 2.6 & 2.8 & \\
\hline & S6 & 2.3 & 2.9 & 3.6 & \\
\hline & Mean \pm SD & $2.11 \pm 0.13$ & $2.93 \pm 0.27$ & $3.13 \pm 0.21$ & \\
\hline
\end{tabular}




\begin{tabular}{|c|c|c|c|c|c|}
\hline \multirow{7}{*}{ Alkalinity (ppm) } & $\overline{\text { S1 }}$ & 415 & 180 & 135 & \multirow{7}{*}{$\begin{array}{l}>100 \mathrm{ppm} \\
{[18]}\end{array}$} \\
\hline & S2 & 365 & 232 & 130 & \\
\hline & S3 & 385 & 236 & 123 & \\
\hline & S4 & 435 & 240 & 147 & \\
\hline & S5 & 425 & 212 & 162 & \\
\hline & S6 & 420 & 260 & 150 & \\
\hline & Mean \pm SD & $407.5 \pm 26.78$ & $266.66 \pm 27.56$ & $141.16 \pm 14.42$ & \\
\hline \multirow{7}{*}{ Hardness (ppm) } & S1 & 216 & 320 & 230 & \multirow{7}{*}{$\begin{array}{l}123 \mathrm{ppm} \\
{[12]}\end{array}$} \\
\hline & S2 & 208 & 332 & 243 & \\
\hline & S3 & 218 & 224 & 256 & \\
\hline & S4 & 203 & 294 & 251 & \\
\hline & S5 & 226 & 222 & 263 & \\
\hline & S6 & 215 & 232 & 238 & \\
\hline & Mean \pm SD & $214.33 \pm 8.02$ & $270.66 \pm 50.56$ & $246.83 \pm 12.16$ & \\
\hline \multirow{7}{*}{$\mathrm{NO}_{3}^{-}(\mathrm{ppm})$} & S1 & 17.05 & 86.16 & 46.43 & \multirow[t]{7}{*}{$10 \mathrm{ppm}$ [22] } \\
\hline & S2 & 2.90 & 2.99 & 49.16 & \\
\hline & S3 & 0 & 89.13 & 47.33 & \\
\hline & S4 & 0 & 88.43 & 44.49 & \\
\hline & S5 & 17.22 & 85.55 & 48.29 & \\
\hline & S6 & 18.71 & 87.15 & 46.57 & \\
\hline & Mean \pm SD & $9.32 \pm 9.22$ & $73.24 \pm 34.44$ & $47.045 \pm 1.63$ & \\
\hline \multirow{7}{*}{$\mathrm{Cl}^{-}(\mathrm{ppm})$} & S1 & 51.68 & 197.51 & 136.39 & \multirow[t]{7}{*}{$600 \mathrm{ppm}[23]$} \\
\hline & S2 & 55.75 & 237.36 & 138.44 & \\
\hline & S3 & 66.63 & 209.75 & 137.95 & \\
\hline & S4 & 62.17 & 207.15 & 136.11 & \\
\hline & S5 & 63.4 & 215.27 & 139.01 & \\
\hline & S6 & 65.25 & 225.14 & 142.05 & \\
\hline & Mean \pm SD & $60.81 \pm 5.85$ & $215.36 \pm 14.12$ & $138.33 \pm 2.1$ & \\
\hline \multirow{7}{*}{ BOD (ppm) } & S1 & 8.1 & 9 & 6 & \multirow{7}{*}{ 5-7 ppm [10] } \\
\hline & S2 & 11 & 7.25 & 3.21 & \\
\hline & S3 & 17.3 & 14 & 6.87 & \\
\hline & S4 & 13.2 & 6.1 & 8.29 & \\
\hline & S5 & 9.5 & 10 & 7.38 & \\
\hline & S6 & 11 & 13.27 & 5.91 & \\
\hline & Mean \pm SD & $11.68 \pm 3.24$ & $9.94 \pm 3.18$ & $6.28 \pm 1.75$ & \\
\hline
\end{tabular}


Table.2: Pearson Correlations among the different parameters of surface water in Sitalakkhyariver in March, 2015.

\begin{tabular}{|c|c|c|c|c|c|c|c|c|c|c|c|}
\hline & Temp. & $\begin{array}{c}\text { Transp } \\
\text { ar. }\end{array}$ & TDS & $\mathrm{EC}$ & $\mathrm{pH}$ & DO & $\begin{array}{c}\text { Alkali } \\
\text { nity }\end{array}$ & $\begin{array}{c}\text { Hardne } \\
\text { ss }\end{array}$ & $\mathrm{NO}_{3}{ }^{-}$ & $\mathrm{Cl}^{-}$ & $\begin{array}{c}\mathrm{BO} \\
\mathrm{D}\end{array}$ \\
\hline Temp. & 1 & & & & & & & & & & \\
\hline Transpar. & 0.617 & 1 & & & & & & & & & \\
\hline TDS & -0.133 & 0.087 & 1 & & & & & & & & \\
\hline $\mathrm{EC}$ & -0.2 & -0.149 & $0.955^{*}$ & 1 & & & & & & & \\
\hline $\mathrm{pH}$ & $0.773^{*}$ & 0.228 & -0.176 & -0.235 & 1 & & & & & & \\
\hline $\mathrm{DO}$ & -0.343 & -0.176 & -0.038 & 0.076 & -0.660 & 1 & & & & & \\
\hline Alkalinity & 0.072 & 0.314 & -0.724 & $-0.745^{*}$ & -0.290 & 0.467 & 1 & & & & \\
\hline Hardness & -0.016 & -0.324 & -0.387 & -0.344 & 0.291 & 0.293 & 0.093 & 1 & & & \\
\hline $\mathrm{NO}_{3}{ }^{-}$ & -0.413 & -0.614 & -0.483 & -0.284 & -0.395 & $0.758 *$ & 0.436 & 0.601 & 1 & & \\
\hline $\mathrm{Cl}^{-}$ & $0.954 *$ & 0.471 & -0.367 & -0.401 & $0.808^{*}$ & -0.251 & 0.196 & 0.239 & -0.173 & 1 & \\
\hline BOD & $0.747^{*}$ & 0.475 & -0.016 & -0.150 & $0.864^{*}$ & $-0.876^{*}$ & -0.298 & -0.186 & $-0.765^{*}$ & 0.657 & 1 \\
\hline
\end{tabular}

* Correlation is significant at 0.01 level (2 tailed).

Table.3: Pearson Correlations among the different parameters of surface water in Sitalakkhyariver in April, 2015.

\begin{tabular}{|c|c|c|c|c|c|c|c|c|c|c|c|}
\hline & Temp. & $\begin{array}{l}\text { Transp } \\
\text { ar. }\end{array}$ & TDS & $\mathrm{EC}$ & $\mathrm{pH}$ & DO & $\begin{array}{c}\text { Alkali } \\
\text { nity }\end{array}$ & $\begin{array}{c}\text { Hardnes } \\
\text { S }\end{array}$ & $\mathrm{NO}_{3}{ }^{-}$ & $\mathrm{Cl}^{-}$ & $\begin{array}{l}\mathrm{B} \\
\mathrm{O} \\
\mathrm{D}\end{array}$ \\
\hline Temp. & 1 & & & & & & & & & & \\
\hline Transpar. & -0.270 & 1 & & & & & & & & & \\
\hline TDS & 0.345 & -0.239 & 1 & & & & & & & & \\
\hline $\mathrm{EC}$ & 0.321 & -0.263 & $0.949 *$ & 1 & & & & & & & \\
\hline $\mathrm{pH}$ & -0.529 & 0.270 & 0.058 & -0.087 & 1 & & & & & & \\
\hline DO & 0.049 & -0.384 & $0.765^{*}$ & 0.602 & 0.112 & 1 & & & & & \\
\hline Alkalinity & -0.005 & -0.266 & -0.668 & -0.483 & -0.693 & -0.528 & 1 & & & & \\
\hline Hardness & -0.530 & -0.060 & 0.529 & 0.493 & 0.244 & $0.745^{*}$ & -0.384 & 1 & & & \\
\hline $\mathrm{NO}_{3}{ }^{-}$ & $0.915^{*}$ & -0.255 & 0.348 & 0.388 & -0.339 & -0.128 & -0.072 & -0.597 & 1 & & \\
\hline $\mathrm{Cl}^{-}$ & -0.599 & 0.314 & $-0.774 *$ & $-0.758^{*}$ & -0.131 & -0.327 & 0.573 & 0.046 & $-0.763^{*}$ & 1 & \\
\hline BOD & 0.508 & -0.313 & -0.425 & -0.539 & -0.149 & -0.275 & 0.289 & $-0.775^{*}$ & 0.421 & -0.005 & 1 \\
\hline
\end{tabular}

* Correlation is significant at 0.01 level (2 tailed). 
Table.4: Pearson Correlations among the different parameters of surface water in Sitalakkhyariver in May, 2015.

\begin{tabular}{|c|c|c|c|c|c|c|c|c|c|c|c|}
\hline & Temp. & $\begin{array}{c}\text { Transp } \\
\text { ar. }\end{array}$ & TDS & $\mathrm{EC}$ & $\mathrm{pH}$ & DO & $\begin{array}{c}\text { Alkali } \\
\text { nity }\end{array}$ & $\begin{array}{c}\text { Hardne } \\
\text { s s }\end{array}$ & $\mathrm{NO}_{3}{ }^{-}$ & $\mathrm{Cl}^{-}$ & BOD \\
\hline Temp. & 1 & & & & & & & & & & \\
\hline Transpar. & 0.264 & 1 & & & & & & & & & \\
\hline TDS & 0.638 & -0.168 & 1 & & & & & & & & \\
\hline $\mathrm{EC}$ & 0.591 & -0.052 & $0.922^{*}$ & 1 & & & & & & & \\
\hline $\mathrm{pH}$ & 0.554 & -0.027 & $0.836^{*}$ & $0.982^{*}$ & 1 & & & & & & \\
\hline DO & -0.010 & -0.411 & -0.019 & -0.314 & -0.437 & 1 & & & & & \\
\hline Alkalinity & 0.629 & 0.193 & 0.314 & 0.342 & 0.326 & 0.360 & 1 & & & & \\
\hline Hardness & 0.312 & 0.479 & 0.373 & 0.678 & $0.764 *$ & -0.718 & 0.300 & 1 & & & \\
\hline $\mathrm{NO}_{3}{ }^{-}$ & 0.099 & $0.906^{*}$ & -0.377 & -0.326 & -0.296 & -0.425 & -0.155 & 0.187 & 1 & & \\
\hline $\mathrm{Cl}^{-}$ & 0.657 & 0.427 & 0.520 & 0.285 & 0.142 & 0.264 & 0.333 & $\begin{array}{l}-0.018 \\
\end{array}$ & 0.347 & 1 & \\
\hline BOD & -0.021 & -0.344 & 0.449 & 0.593 & 0.611 & 0.052 & 0.450 & 0.484 & -0.686 & -0.272 & 1 \\
\hline
\end{tabular}

* Correlation is significant at 0.01 level (2 tailed).

\section{CONCLUSION}

The present status of waste water management in Bangladesh is not satisfactory and most of the waste water is discharged indiscriminately without maintaining any sort of proper steps which is degrading the water quality critically. The present study was conducted to evaluate the physicochemical parameters of water collected from 6 sites of Sitalakkhyariver from March- May, 2015 and observe temporal changes of the parameters. According to the study, water temperature, transparency, TDS, EC, pH, DO, alkalinity, hardness, $\mathrm{NO}_{3}{ }^{-}, \mathrm{Cl}^{-}, \mathrm{BOD}$ were ranged from 31.5$34.6^{0} \mathrm{C}, \quad 15.25-27.30 \mathrm{~cm}, 291-781 \mathrm{ppm}, 558-2664 \mathrm{ppm}$, 7.57-8.60, 1.4-3.6 ppm, 123-435 ppm, 203-332 ppm, 0$89.13 \mathrm{ppm}$, 51.68-237.36 ppm and 3.21-17.3 ppm, respectively indicating presence of high organic and inorganic compounds or pollutants in water.

In the study, $\mathrm{pH}$ showed significant strong positive correlation with $\mathrm{Cl}^{-}(\mathrm{r}=0.808, \mathrm{p}<0.05)$ and BOD $(\mathrm{r}=0.864$, $\mathrm{p}<0.05)$ in March and hardness $(r=0.764, \mathrm{p}<0.05)$ in May; DO showed significant strong positive correlation with $\mathrm{NO}_{3}{ }^{-}(\mathrm{r}=0.758, \mathrm{p}<0.05)$ in March and hardness $(\mathrm{r}=0.745$, $\mathrm{p}<0.05)$ in April; DO showed significant strong negative correlation with BOD ( $\mathrm{r}=-0.876, \mathrm{p}<0.05)$ in March; hardness showed significant strong negative correlation with BOD ( $\mathrm{r}=-0.775, \mathrm{p}<0.05)$ in April and $\mathrm{NO}_{3}{ }^{-}$showed significant strong negative correlation with BOD $(r=-0.765$, $\mathrm{p}<0.05)$ in March and $\mathrm{Cl}^{-}(\mathrm{r}=-0.763, \mathrm{p}<0.05)$ in April.
The present study found that the physicochemical condition of Sitalakkhya River was very poor in the month of March and April. But with the increase in the water flow the condition improved slightly in the month of May. From the compression with the previous year's data the study found that the situation is getting worse with time.

\section{REFERENCES}

[1] Ahmed, T. and Badruzzaman, A.B.M.(2007). Effect ofthermal effluenton water quality of Sitalakhya river,The Institution of Engineers, Bangladesh. Journal of Civil Engineering.35(1), 59-70.

[2] Alam, M. J. B., Islam, M. R., Muyen, Z., Mamun, M. and Islam, S. (2007). Waterquality parameters along Surmarivers. International Journal of Science and Technology, Winter.4 (1), 159-167.

[3] Burton, G.A., Jr., and Pitt, R.E.(2002). Storm Effects Handbook: A Toolbox for Watershed Managers, Scientists, and Engineers. Lewis Publishers, Boca Raton, FL.

[4] Bhoumic, U., Das, P. and Paria, T.(2006). Impact of Industrial pollution on the Biology of the River Karnafuli. Department of Zoology, University of Chittagong, Bangladesh.

[5] Chapman, M.K. and Kimstach, V.(1996). "Selection of Water Quality Variables," In Water Quality Assessment: A Guide to Use of Biota, Sediments and Water in Environmental Monitoring, $2^{\text {nd }} e d$. 
[6] Das, G.S., Tiwari, B.K. and Tripathi, R.S.(2002).

"Coal mining in jaintiahills,Meghalaya: An ecological perspective,"In:jaintiahills, Meghalaya Tribe: Its Environment, Land and People. Reliance Publishing House, New Delhi, pp.121-128.

[7] DHV(1998). Meghna Estuary Study. Draft Master Plan, Volume 1, Main Report for BWDB, Dhaka, Bangladesh.

[8] DoE and LGED(2010). Limited environmental \& social impact assessment and environmental \& social management framework Bangladesh: Dhaka environment and water project. Volume 1, Department of Environment and Local Government Engineering Department, Bangladesh.

[9] Ellis, M.M.B.A., Westfall and Ellis, M.D.(1946). "Determination of Water Quality. Fish and Wildlife Services,"U. S. Dept. Interior, Res Rept. In Welch, P. S. 1952.Limnology, $2^{\text {nd }}$ ed., vol.9, pp.11. McGrawHill Book Company, New York, pp. 182.

[10] EPA (Environmental Protection Agency), U. S. (2001). Drinking Water Criteria Document for Silver (Final Draft). Environmental Criteria and Assessment Office, Cincinnati, OH. ECAO-CIN-026, PB 86118288.

[11] EQS (Environmental Quality Standard).(1997). Bangladesh Gazette, registered nr.DA-1, Ministry of Environment, Government of Bangladesh.

[12] Huq, S.M.I. and Alam, M.D.(2005). A hand book of analysis of Soil, Plant and Water. BACERDU, University of Dhaka, Bangladesh, Xxii-pp.246.

[13] Islam, J. B., Sarker, M., Rahman, A. K. M. L. and Ahmed, K. S.(2015). Quantitative assessment of toxicity in the Shitalakkhya River, Bangladesh (in press). Egyptian Journal of Aquatic Research, http://dx.doi.org/10.1016/j.ejar.2015.02.002.
[14] Karanth, K. R.(1994). Ground Water Assessment, Development and Management. Tata McGraw-Hill Publishing Company Ltd, New Delhi, India, pp. 248250.

[15] Karn, S. K. and Harada, H. (2001). Surface water pollution in three urban territories of Nepal, India, and Bangladesh. Environmental Management. 28(4): 438496.

[16] Meade, J. W.(1998). Aquaculture Management. CBS Publisher and Distributors, New Delhi, India, pp. 9.

[17] Rabbani, G. and Sharif, M.I. (2005). Dhaka City state of Environment (SoE). UNEP in collaboration with BCAS and DoE, pp. 40.

[18] Rahman, M.S. (1992). Water quality management in aquaculture. BRAC Prokashana, Bangladesh, pp. 84.

[19] Sawyer, C.N., McCarty, P.L. and Parkin, G.F. (2003). Chemistry for Environmental Engineering and Science. $5^{\text {th }}$ ed., New York, McGraw-Hill.

[20] Sikder, M. T., Yasuda, M, Yustiwati, Syawal, S. M., Saito, T., Tanaka, S. and Kurasaki, M.(2012). Comparative Assessment of water quality in the major river of Dhaka city and west java. International Journal of Environmental Protection (IJEP),2: 8-13.

[21] Trivedy, R.K. and Goel, P.K. (1984). Chemical and biological methods for water pollution studies. Environmental publications, KARAD, pp. 42-74.

[22] USEPA(1994). Drinking Water Regulations and Health Advisories, Office of Water U.S. Environmental Protection Agency, Washinton, D.C. 202-260-7571.

[23] WHO(1993). Guidelines for Drinking Water Quality, World Health Organization, Geneva, Switzerland. 